hal ini merupakan akibat dari kurangnya pemahaman masyarakat tentang manfaat pendidikan seni.

Demikian pula, Tjetjep Rohendi Rohidi (2005: 100) menyatakan bahwa pendidikan seni di Indonesia masih dipandang kurang penting dan bahkan terabaikan. Permasalahan mendasar tersebut memberikan dampak pada lemahnya pelaksanaan pendidikan seni di lapangan. Para pelaksana pendidikan seni pada umumnya tidak begitu memperhatikan konsep-konsep yang melandasi pendidikan seni dan hanya menyelesaikan pembelajaran seni di kelas secara praktis Kelemahan pelaksanaan pendidikan seni antara lain terdapat pada aspek penilaian hasil belajar. Penilaian hasil belajar yang dilakukan baru terfokus pada aspek kognitif dan aspek psikomotor, sehingga penilaian ranah afektif masih terabaikan. Mengingat pentingnya aspek afektif dalam pendidikan seni, seharusnya penilaian afektif juga menjadi bagian penting dari penilaian pendidikan seni.

Dalam pendidikan seni rupa, penilaian afektif berkaitan dengan pembelajaran apresiasi seni rupa. Apresiasi seni rupa adalah pengenalan dan penghayatan terhadap karya seni rupa. Di jenjang pendidikan dasar dan menengah siswa diperkenalkan kepada berbagai bentuk karya seni rupa, baik yang berasal dari Nusantara maupun dari mancanegara. Tujuan utama pembelajaran apresiasi seni rupa adalah mengembangkan sensitivitas dan penghargaan siswa terhadap karya seni rupa. Namun demikian, penilaian yang terkait dengan tujuan pembelajaran afektif ini belum tampak dilakukan. Tes apresiasi seni rupa yang dilakukan pada umumnya baru terbatas pada aspek kognitif.

Penilaian afektif merupakan kebutuhan yang mendesak dalam pelaksanaan penilaian hasil belajar seni di sekolah. Hal ini sesuai dengan Penjelasan Peraturan Pemerintah Republik Indonesia Nomor 19 Tahun 2005 tentang Standar Nasiona Pendidikan, Pasal 22 Ayat (1), yang berbunyi "Penilaian hasil pembelajaran mencakup aspek kognitif, psikomotorik, dan/atau afektif sesuai dengan karakteristik mata pelajaran" (Peraturan Pemerintah, 2005: 80)

Sehubungan dengan hal tersebut, untuk melaksanakan penilaian afektif dalam pendidikan seni rupa, pertama-tama perlu dilakukan pengembangan instrumen pengukuran afektif. Instrumen pengukuran afektif ini khususnya digunakan untuk mengukur tanggapan siswa terhadap karya seni rupa. Tanggapan terhadap karya seni rupa ini disebut respons estetik (aesthetic response) (Papa, 2006: 3).

Untuk mengukur respons estetik tersebut, diperlukan instrumen pengukuran nontes. Jenis instrumen yang memenuhi keperluan tersebut adalah semantic differential, yang dikembangkan oleh Osgood, Suci, dan Tannenbaum. Dalam penelitian ini, semantic differential diterapkan untuk mengukur respons estetik siswa Sekolah Menengah Pertama. Sehubungan dengan hal itu, diajukan pertanyaan penelitian sebagai berikut:

\section{PERTUNJUKAN FRAGMEN SUMILAKE PEDHUT KATANGGA DALAM RITUAL BATHOK BOLU PADA MASYARAKAT} SAMBIROTO PURWOMARTANI KALASAN SLEMAN

Herlinah dan Titik Putraningsih Fakultas Bahasa dan Seni Universitas Negeri Yogyakarta

Abstract

This study is aimed at identifying the performance form of Sumilake Pedhut Katangga Fragment in the ritual art Bathok Bolu in Sambiroto village, Purwomartani Kalasan Sleman, where the research was conducted. The subject P the he village and staff from Tourism Bureau of Sleman regency. The research dat were taken through library research, observation, documentation and interview. The approach used was qualitative. The result shows that the fragmen performance in the ritual ceremony Bathok Bolu is performed on the tenth of Sura annually. The tradition is held for the sake of bersih desa in Kajiman Alas Katangga Palace. This functions as social appreciation, entertainment, aesthetic presentation, economic support, and identity of governmental power.

Keywords: Sumilake Pedhut Katangga fragment, ritual art and performance art

\section{PENDAHULUAN}

Kebudayaan adalah hasil karya manusia dalam kehidupan bermasayakat yang dicetuskan sesudah melalui suatu proses belajar (Koentjaraningrat, 2000: 1). Pendapat tersebut memiliki makna bahwa perwujudan kebudayaan merupakan system kegiatan perilaku warga masyarakat sebagai pendukungnya. Salah satu wujud dari kebudayaan adalah kesenian. Kesenian sebagai bagian dari kebudayaan memiliki sifat dan hakikat yang sama yaitu universal, stabil, dinamis, dan juga menentukan jalannya kehidupan manusia. Kesenian sebagai unsur kebudayaan mrupakan hasil ekspresi manusia yang mengandung nilai keindahan. Kesenian adalah hasil kemampuan, kegiatan daya, rasa, dan karsa manusia sehingga wajar bila ia tumbuh dan berkembang sesuai dengan perkembangan kreativitas masyarakatnya. Yang paling penting, setiap wujud kesenian memiliki ciri-ciri khusus sesuai dengan situasi dan lokasi di mana seni tersebut berada.

Hal tersebut di atas sesuai dengan apa yang dikatakan Kayam (1981:39) bahwa: Kesenian tidak pernah berdiri lepas dari masyarakatnya. Sebagai salah satu bagian yang penting dari kebudayaan, kesenian adalah ungkapan kreativitas dari kebudayaan itu sendiri. Masyarakat yang menyangga kebudayaan dan dengan demikian juga kesenian mencipta, memberi peluang untuk bergerak, memelihara, menularkan, mengembangkan untuk kemudian menciptakan kebudayaan baru lagi. 
atau bahasa visual yang di dalamnya terkandung unsur-unsur dan struktur rupa seperti garis, bidang warna dan komposisi, untuk menyampaikan sebuah konsep, isi atau makna, atau pesan yang hendak disampaikan.

Pesan yang disampaikan melalui media lukisan digolongkan menjadi dua macam, yaitu :

1. Berupa lukisan representasional, penggambarannya mewakili bentuk-bentuk yang ada di alam, dan obyektif. Penggambaran secara realistik menggunakan simbol-simbol yang sudah akrab dengan bentuk yang ada di alam (ada kemiripan), sehingga masyarakat apresian mudah menangkap informasi atau pesan, yang disampaikan dan menangkap maknanya.

2. Bentuk lukisan non representasional, penggambaran ide-ide obyek idiil, melalui simbol-simbol garis bidang, warna yang disusun sedemikian rupa, sering kali masyarakat awam sulit untuk menangkap maknanya. Ini berarti komunikasi tidak dapat berjalan seperti yang diharapkan. Oleh karena itu, pelukis perlu kiranya menerapkan prinsip-prinsip komunikasi, dengan mengkondisikan faktor pendukung, dan dalam penciptaan bentuk berupa lambang diupayakan komunikatif atau diberikan penjelasan secara verbal untuk melengkapinya, sehingga pesan yang disampaikan sama dengan yang ditangkap.

Dalam pameran lukisan sebagai bentuk komunikasi, apresian akan memberikan tanggapan terhadap lukisan yang dipamerkan. Oleh karenanya, pesan yang ditangkap harus maksimal dan menarik baik dari segi karya yang ditampilkan maupun display karya, pencahayaan, musik serta hal-hal yang terkait dengan ceremonialnya. Penampilan optimal tersebut akan direspon secara baik oleh apresian, dan ini merupakan awal kesuksesan dalam proses komunikasi.

\section{DAFTAR PUSTAKA}

Sobur, Alex. 2003. Semiotika Komunikasi. Bandung, PT. Remaja Rosda Karya Bandung,

Feldman, Edmund Burke. 1967. Art as Image and Idea. Prentice - Hall, Inc., Englewood Cliffs, New Jersey

Sahman, Humar. 1993Mengenali Dunia Seni Rupa: Tentang Seni, Karya Seni, Aktivitas Kreatif, Apresiasi, Kritik dan Estetika. Semarang, IKIP Semarang Press

Efendi, Onong Uchjana. 2003. Ilmu, Teori dan Filsafat Komunikasi. Bandung, PT. Citra Aditya Bakti.

Soedarso Sp. 1990. Sejarah Perkembangan Seni Rupa Modern. Yogyakarta, Saku Dayar sana

Sumbo Tinarbuko. 2008. Semiotika Komunikasi Visual. Yogyakarta, Jalasutra. Gie, The Liang. 1983. Garisbesar Estetik (Filsafat Keindahan).
1. Bagaimana prosedur pengembangan instrumen pengukuran estetik yang valid dan reliabel dengan menggunakan semantic differential untuk siswa Sekolah Menengah Pertama?

2. Bagaimana karakteristik instrumen pengukuran respons estetik siswa Sekolah Menengah Pertama yang dikembangkan berdasarkan analisis faktor?

3. Sejauh mana reliabilitas instrumen pengukuran respons estetik siswa Sekolah Menengah Pertama yang dikembangkan?

4. Sejauh mana instrumen pengukuran respons estetik siswa Sekolah Menengah Pertama yang dikembangkan memiliki sensitivitas terhadap karakteristik karakteristik karya seni rupa?

Sementara itu, tujuan penelitian ini adalah sebagai berikut:

1. Memperoleh instrumen pengukuran respons estetik siswa Sekolah Menengah Pertama yang valid dan reliable dengan menggunakan semantic differential.

2. Mengungkap karakteristik instrumen pengukuran respons estetik siswa Sekolah Menengah Pertama yang dikembangkan sesuai berdasarkan analisis faktor.

3. Mengungkap reliabilitas instrumen pengukuran respons estetik siswa Sekolah Menengah Pertama yang dikembangkan.

4. Mengungkap sensitivitas instrumen pengukuran respons estetik siswa Sekolah Menengah Pertama yang dikembangkan terhadap karakteristik karya seni rupa?

\section{KAJIAN TEORI}

Suatu instrumen pengukuran harus memenuhi syarat validitas dan reliabilitas. Menurut Allen dan Yen (1979: 95), suatu tes dikatakan valid jika dapat mengukur apa yang seharusnya diukur. Secara umum terdapat tiga macam validitas, yaitu validitas isi (content validity), validitas kriteria (creterion-related validity), dan validitas konstruk (construct validity) (Kerlinger, 1986: 417). Untuk menguji validitas instrumen pengukuran afektif, dapat digunakan salah satu atau semua jenis validitas berikut: validitas isi, validitas konstruk, dan validitas kriteria (Fernandes, 1984: 73-74).

Validitas isi dinilai melalui analisis rasional terhadap isi suatu tes dan penentuannya didasarkan pada penilaian subjektif dan individual (Allen dan Yen 1979: 95). Validitas isi biasanya diuji dengan penilaian personal oleh ahli di bidangnya. Validitas isi didasarkan pada keputusan penilaian (bersifat judgmental). Validitas kriteria diteliti dengan membandingkan suatu tes atau skala dengan satu atau lebih ubahan-ubahan eksternal, atau kriteria yang dianggap mengukur kualitas yang diteliti (Kerlinger, 1986: 418). Validitas konstruk (construct validity) suatu tes adalah sejauh mana tes tersebut mengukur konstruk atau trait teoretik yang ingin diukur. Menurut Kerlinger (1986: 427) metode yang 
digunakan untuk meneliti validitas konstruk adalah analisis faktor.

Reliabilitas juga disebut sebagai dependabilitas, stabilitas, konsistensi, prediktabilitas, atau akurasi. Reliabilitas dan dependabilitas menunjukkan suatu pengukuran yang dapat diandalkan atau dapat dipercaya. Stabilitas, konsistensi, dan prediktabilitas menunjukkan pengukuran yang tidak relatif berubah-ubah, sehingga dapat diprediksi hasilnya. Prediktabilitas menunjukkan pengukuran yang dapat diduga (Kerlinger, 1986: 407)

Salah satu pendekatan dasar untuk mengukur reliabilitas adalah stabilitas. Stabilitas diperoleh dengan mengkorelasikan skor siswa dari dua kali pelaksanaan tes, dengan korelasi intraklas (interclass correlation). Estimasi reliabilitas didefinisikan sebagai perbandingan (rasio) antara true score variance dengan observed variance (Nachmias \& Nachmias, 1981: 148). Menurut Borg dan Gall (1983: 284), reliabilitas tes-retes disebut koefisien stabilitas (coefficient of stability). Reliabilitas tes-retes sangat cocok untuk tes yang mengukur trait (sifat), misalnya tes untuk mengukur ketajaman pengamatan visual dan auditori (Allen dan Yen, 1979: 76-77). Jika digunakan untuk keputusan individual, batas minimum reliabilitas adalah 0,9 , sedangkan untuk menarik kesimpulan tentang kelompok 0,5 (Fernandes, 1984: 73)

Semantic differential adalah salah satu bentuk instrumen pengukuran yang berbentuk skala, yang dikembangkan oleh Osgood, Suci, dan Tannenbaum. Instrumen ini juga digunakan untuk mengukur reaksi terhadap stimulus, kata-kata dan konsep-konsep dan dapat disesuaikan untuk orang dewasa atau anak-anak dari budaya manapun juga (Heise, 2006: 1). Semantic differential digunakan untuk dua tujuan: (1) untuk mengukur secara objektif sifat-sifat semantik dari kata atau konsep dalam ruang semantik tiga dimensional dan (2) sebagai skala sikap yang memusatkan perhatian pada aspek afektif atau dimensi evaluatif (Issac dan Michael, 1984: 144-145). Osgood dkk (Issac dan Michael, 1984: 145) menemukan tiga dimensi atau faktor utama, yaitu dimensi evaluatif (evaluative) misalnya "bagus-jelek", dimensi potensi misalnya "keras-lunak", dan dimensi aktivitas misalnya "cepat-lambat".

Analisis data untuk semantic differential yang khas adalah analisis faktor (Sytsma, 2006: 2). Analisis faktor menunjukkan berbagai macam teknik statistik yang memiliki tujuan umum menyajikan seperangkat ubahan dalam sejumlah kecil ubahan hipotetik (Kim dan Mueller, 1978: 8-12). Menurut Garson (2006: 2), ada dua jenis analisis faktor, yaitu analisis faktor eksploratori dan analisis faktor konfirmatori. Analisis faktor eksploratori berusaha menemukan struktur dasar yang melandasi sejumlah besar ubahan. Di sini tidak diperlukan teori sebelumnya dan muatan faktor digunakan untuk menentukan secara intuitif stuktur faktor dar data yang dianalisis. Analisis faktor konfirmatori bertujuan menetapkan apakah b. Lukisan non representative, yang bentuk lukisannya abstrak (pengabstraksian bentuk atau non figuratif), bentuk visualnya berupa lambang, subyektif, maka perlu adanya tafsir-tafsir terhadap pesan yang berupa simbol atau tanda yang diciptakan. Oleh karenanya, untuk lukisan abstrak tersebut perlu penjelasan secara verbal untuk melengkapinya, agar pesan yang disampaikan sama seperti yang ditangkap.

Butir 3 : Dalam lukisan, pesan yang dapat membangkitkan kebutuhan pribadi pada umumnya adalah mengandung nilai-nilai yang sifatnya universal, yaitu: lukisan sifatnya komunikatif, indah, terkait dengan nilai-nilai kebenaran, kebaikan, dan pendidikan. Secara khusus, karya harus kreatif dan mengandung nilai kebaruan, baik dari segi tema, bentuk, maupun tekniknya. Misalnya: dari segi tema, menyampaikan hal-hal yang aktual dan humanis. Sebagai contoh: Tema pemilu 2009, masalah cinta, pemanasan global, dan sebagainya. Dari segi bentuk, melahirkan bentuk-bentuk baru yang belum pernah ada sebelumnya. Sedangkan teknik, menggunakan multimedia.

Butir4 : Melalui pameran lukisan, apresian akan memberikan tanggapan terhadap lukisan yang dipamerkan. Oleh karenanya, diperlukan persiapan yang matang dalam menampilkan karya-karya lukisannya, baik dari karyanya sendiri, tema harus aktual dan kreatif. Penyajiannya sempurna, dari display karya, tata cahaya dan acara yang terkait dengan ceremonialnya. Sehingga, pesan yang luar biasa dalam penyelenggaraan pameran lukisan dapat ditangkap atau direspon secara baik oleh apresian.

Empat faktor yang disebutkan di atas, secara umum merupakan suatu kondisi yang perlu diperhatikan oleh komunikator agar tujuan komunikasi dapat berjalan secara baik.

Adapun bagi komunikan atau apresiator agar komunikasi berjalan secara baik, maka yang perlu diperhatikan adalah :

1. Ia dapat benar-benar mengerti pesan komunikasi.

2. Pada saat ia mengambil keputusan, ia sadar bahwa keputusannya itu sesuai dengan tujuannya.

3. Pada saat ia mengambil keputusan ia sadar bahwa keputusannya itu bersangkutan dengan kepentingan pribadinya.

4. Ia mampu untuk menepatinya baik secara mental maupun fisik.

\section{SIMPULAN}

Dari uraian bab-bab sebelumnya, maka dapat diperoleh kesimpulan bahwa pelukis sebagai individu membutuhkan berkomunikasi dengan manusia di luar dirinya. Melalui bentuk signifikan dalam lukisan yang merupakan wujud simbol 
masyarakat apresian lebih mudah menangkap informasi melalui tanda atau simbol yang sudah akrab dan terlibat di dalamnya, dan ini sering terlihat dalam realitas kehidupan sehari-hari. Hal ini akan berbeda jika dibandingkan dengan lukisan non representasional, yang bentuk visualisasinya menggunakan tanda atau simbol yang sifatnya individual dan subyektif. Maka, di dalam berkomunikasi diperlukan sejumlah pengetahuan yang memadai tentang siapa target sasaran yang akan dituju, dan bagaimana cara sebaik-baiknya berkomunikasi dengan mereka Semakin baik dan lengkap pemahamannya terhadap hal-hal tersebut, maka akan semakin mudah untuk menciptakan bahasa visual yang komunikatif, agar tujuan komunikasi dapat berhasil dengan baik.

\section{FAKTOR PENDUKUNG DAN PENGHAMBAT DALAM PROSES}

\section{KOMUNIKASI}

Membahas lebih lanjut masalah tujuan komunikasi agar tercapai seperti yang diharapkan, atau suatu pesan dapat membangkitkan tanggapan seperti yang dikehendaki, menurut Wilbur Schramm yang dikutip oleh Onong Uchjana Effendy (2003: 41), terdapat beberapa hal yang harus dikondisikan. Kondisi tersebut dapat dirumuskan sebagai berikut:

1. Pesan harus dirancang dan disampaikan sedemikian rupa, sehingga dapat menarik perhatian komunikan.

2. Pesan harus menggunakan lambang-lambang tertuju kepada pengalaman yang sama antara komunikator dan komunikan, sehingga sama-sama mengerti.

3. Pesan harus membangkitkan kebutuhan pribadi komunikan, dan menyarankan beberapa cara untuk memperoleh kebutuhan tersebut.

4. Pesan harus menyarankan suatu jalan untuk memperoleh kebutuhan tadi yang layak bagi situasi kelompok dimana komunikan berada pada saat ia digerakkan untuk memberikan tanggapan yang dikehendaki.

Dari pendapat tersebut, dapat diperjelas dengan uraian sebagai berikut:

Butir 1 : Bagi penulis, perlu ide-ide kreatif dan kebaruan (novelty) baik dari segi tema, bentuk, bahan, dan teknik yang ditampilkan. Kebaruan inilah yang menjadi menarik untuk dilihat.

Butir 2 : Dalam dunia seni lukis, terdapat dua bentuk penyampaian (penggambaran), yaitu :

a. Lukisan representatif, yang menyampaikan pesan melalui bentuk realistik, sifat penggambarannya seperti senyatanya, alam sebagai patokan, obyektif, dan terdapat salah benar. Oleh karenanya, ketika pelukis menggambarkan obyek-obyek yang hasilnya tidak sesua dengan yang terdapat di alam, maka dianggap salah, kurang persi atau tidak berhasil. Lambang atau tanda yang digunakan, baik komunikator dan komunikan terdapat kesamaan. jumlah faktor dan muatan faktor dari ubahan-ubahan indikator pada faktor-faktor tersebut sesuai dengan apa yang diharapkan, berdasarkan teori yang ditentukan sebelumnya.

Penyusunan suatu instrumen pengukuran harus mempertimbangkan perkembangan siswa. Siswa SMP memiliki usia sekitar 12 tahun sampai 15 tahun. Menurut Piaget (Woolfolk \& McCune-Nicolich, 1984: 60), anak usia 11 sampai 15 tahun termasuk pada tahap formal operasional. Ciri-ciri anak usia ini antara lain mampu memecahkan masalah abstrak secara logis dan berpikir ilmiah. Dalam periodisasi perkembangan seni rupa, siswa SMP termasuk dalam tahap pseudonaturalistik. Pada tahap ini siswa telah memiliki perhatian terhadap warna dan ciriciri desain (Lowenfeld \& Brittain, 1975: 310). Pada tahap ini, siswa juga telah memiliki kesadaran tentang keindahan (Lowenfeld \& Brittain, 1975: 323). Lansing (1976: 185), sejak umur 11 tahun, anak memasuki tahap keputusan artistik (artistic decision stage). Pada tahap ini anak telah memahami bahwa seni rupa merupakan proyeksi pikiran dan perasaan. Hal ini berarti bahwa ia juga mampu merespon karya orang lain dengan sensitivitas yang sama. Ia telah dapat menikmati pengalaman estetik. Ia cenderung menyukai seni rupa yang naturalistik, tetapi mampu mengapresiasi bentuk-bentuk seni rupa yang lain. Selanjutnya, menurut Lansing (1976: 306-308), sejak Kelas VII siswa telah memiliki kesadaran dan perhatian terhadap estetika.

Mengukur respons estetik siswa merupakan upaya untuk mengetahui kemampuan afektif siswa. Anak dapat diminta untuk merespon beberapa lukisan dengan tema yang berbeda-beda untuk mengetahui apakah responsnya juga akan berbeda-beda, antara lain kualitas afektif, yaitu perasaan terhadap lukisan itu dan unsur-unsur desain, warna, garis, bentuk, tekstur, dan ruang dan hubunganhubungannya (McFee, 1970: 291-292).

Selain valid dan reliabel, instrumen pengukuran respons estetik siswa harus memiliki sensitivitas terhadap karakteristik karya seni rupa. Karya seni rupa memiliki unsur tema dan gaya. Tema dapat diartikan sebagai stimulus yang menjadi sumber pikiran dan perasaan yang diungkapkan seniman (Ocvirk dkk, 1982: 10). Menurut Chapman (Humar Sahman, 1993: 41-50), gaya adalah kemiripan dalam kelompok di antara karya-karya seni rupa yang ditandai dengan sifat-sifat umum yang dimiliki bersama. Gaya juga dapat diartikan sebagai cara berkarya dan pendekatan teknis tertentu dalam penciptaan seni rupa (Feldman, 1967: 138). Oleh seniman, tema diperlakukan secara bertingkat-tingkat yang secara umum dapat menjadi tiga tingkatan yaitu representasional, abstrak, dan nonobjektif(Cleaver, 1966: 29).

Menurut Ocvirk dkk. (1962: 10), tema juga berarti topik atau motif suatu karya seni rupa. Tema hampir selalu dijumpai pada karya seni rupa, meskipun karya seni rupa itu bergaya abstrak, yaitu karya seni rupa yang menggambarkan 
tema atau objek secara menyimpang dari kenyataan. Cleaver (1966: 29) mendefinisikan tema sebagai objek-objek (yang dapat dikenal) yang digambarkan oleh seniman. Tema merupakan semua objek yang terdapat di alam semesta, yaitu manusia, alam benda, tumbuh-tumbuhan, dan binatang. Objek-objek ini dapa digambarkan secara sendiri-sendiri maupun secara gabungan.

Penelitian tentang respons estetik telah dilakukan oleh banyak peneliti. Hoege (1984: 40-41) misalnya meneliti tentang pengaruh emosi terhadap penilaian estetik (aesthetic judgment). Hoege menggunakan semantic differentia yang terdiri atas 16 butir pasangan kata sifat untuk menilai reproduksi lukisan. Berdasarkan analisis faktor, Hoege menemukan bahwa konstruk penilaian estetik meliputi empat faktor, yaitu empati, emosi, aktivitas, dan kejelasan. Menurut hasilhasil penelitian, gaya dan tema berpengaruh terhadap respons estetik siswa Newton (1989: 81-82) Selain itu, ditemukan pula bahwa tema dan gaya berpengaruh secara interaktif terhadap respons estetik siswa.

\section{METODE PENELITIAN}

Penelitian pengembangan ini menggunakan model prosedural. Dalam penelitian ini instrumen pengukuran respons estetik yang dikembangkan berupa semantic differential dengan reproduksi (foto) lukisan sebagai objek tanggapan. Pengembangan instrumen ini meliputi langkah-langkah sebagai berikut: (1) pembuatan kisi-kisi, (2) penyusunan skala, (3) telaah dan perbaikan instrumen, (4) uji coba produk, dan (5) analisis hasil uji coba.

Instrumen pengukuran ini diujicobakan terhadap 70 siswa Kelas VII SMP Negeri 4 Yogyakarta tahun ajaran 2006/2007. Dalam uji coba ini siswa diminta untuk mengamati dan memberikan tanggapan terhadap 12 buah foto lukisan secara berturut-turut. Tanggapan siswa di sini diberikan dengan mengisi lembar tanggapan berupa semantic differential, dengan mengisi satu lembar tanggapan untuk masing-masing lukisan. Pengukuran respons estetik siswa ini dilakukan sebanyak dua kali dengan selang waktu satu minggu.

Analisis data dalam penelitian ini meliputi analisis kualitatif dan analisis kuantitatif. Analisis kualitatif dilakukan dengan kaji ulang terhadap instrumen yang dikembangkan oleh empat orang dosen Jurusan Pendidikan Seni Rupa FBS Universitas Negeri Yogyakarta. Analisis kuantitatif meliputi analisis faktor, analisis reliabilitas, dan analisis stabilitas (korelasi intraklas). Selain itu, dilakukan ANAVA dengan pengukuran ulang untuk mengetahui sensitivitas instrumen yang dikembangkan, yaitu menguji pengaruh faktor gaya dan tema terhadap respons estetik siswa. Seluruh analisis statistik ini dilakukan dengan menggunakan program SPSS 10.0
Lukisan yang merupakan manifestasi ide, diekspresikan melalui bentukbentuk signifikan menggunakan garis, bidang, warna, pada bidang dua dimensional. Bentuk signifikan tersebut menyampaikan pesan melalui tanda atau simbol menggunakan bahasa garis, bentuk, warna, tekstur, gelap terang, atau obyek-obyek tertentu. Simbol dan tanda yang dihasilkan akan selalu mengacu, atau mewakili suatu hal (obyek/benda) yang sifatnya riil atau idiil. Misalnya: lukisan menggambarkan garis sudut menyudut tajam, kaku, dengan warna merah gelap sampai kuning dengan komposisi asimetrik balance, menyampaikan pesan tentang kekeringan, terik, gersang, panas, dan seterusnya. Begitu pula pada lukisan yang sifatnya realistik penggambaran wajah cerah, gemuk, segar, menggambarkan simbol (tanda) kebahagiaan, sehat, dan sebagainya.

Pesan yang disampaikan melalui bentuk visual menggunakan tanda/simbol yang mengacu pada hal mewakili, sehingga dalam benak yang melihat akan timbul pengertian. Tentang hal tersebut (informasi yang ditangkap) menurut Pierce, tanda (representamen) ialah sesuatu yang dapat mewakili sesuatu yang lain dalam batas tertentu. Tanda selalu mengacu ke sesuatu yang lain. Mengacu berarti mewakili atau menggantikan. Tanda baru dapat berfungsi bila diinterpretasikan dalam benak penerima tanda melalui pemahaman makna yang muncul dalam diri penerima tanda. Artinya, tanda baru dapat berfungsi sebagai tanda bila dapat ditangkap, dan pemahaman terjadi berkat pengetahuan tentang sistem tanda dalam suatu masyarakat (seni). Tanda dalam hubungannya dengan acuannya dibedakan menjadi tanda yang dikenal dengan ikon, indeks, dan simbol (Alex Sobur, 2003 : 35). Pierce dalam Berger (2000 : 14) yang dikutip oleh Alex Sobur (2003 : 34) menandakan bahwa tanda-tanda berkaitan dengan obyek-obyek yang menyerupainya, keberadaannya memiliki hubungan sebab-akibat dengan tandatanda atau karena ikatan konvensional dengan tanda-tanda tersebut. Ia menggunakan istilah ikon, untuk kesamaannya, indeks untuk hubungan sebabakibat, dan simbol untuk asosiasi konvensional. Menurut Pierce, sebuah analisis tentang esensi tanda mengarah pada pembuktian bahwa setiap tanda ditentukan oleh obyeknya.

Tanda baik ikon, indeks maupun simbol penting fungsinya untuk menangkap pesan yang diinformasikan melalui bentuk visual dari sebuah lukisan yang berupa obyek, dengan berbagai karakternya, pewarnaan yang digunakan, atau relasinya, komposisinya, serta bahan dan teknik yang digunakannya.

Seni lukis dalam penggolongannya dapat bersifat representasional dan non representasional. Lukisan representasional penggambarannya mewakili bentukbentuk yang ada di alam dan obyektif. Penggambaran obyek-obyeknya seperti yang ada atau terdapat di alam, sifatnya realistik. Oleh karenanya, untuk menyampaikan pesan melalui penggambaran bentuk-bentuk, lambang, ikon, atau tanda-tanda yang mewakili bentuk yang ada di alam (ada kemiripan), sehingga 


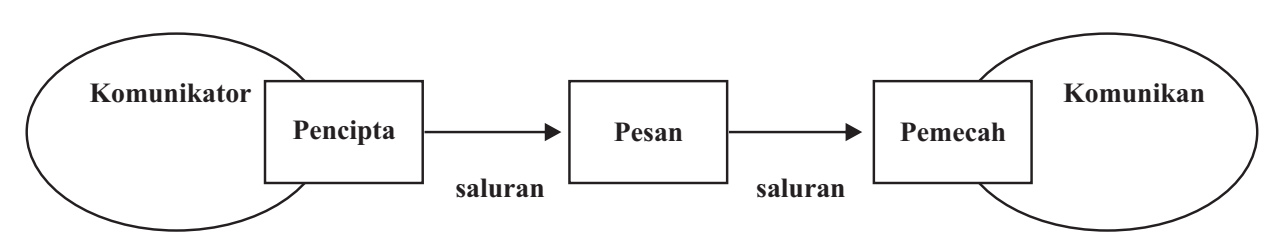

Jika dilihat pada model komunikasi menurut Adler dan Rodman ini, pelukis sebagai orang yang mencoba menyampaikan gagasan. Gagasan yang ingin dikemukakan ini masih berupa gambaran mental, yang terdiri dari perasaan atau gagasan yang belum berupa rumusan simbol-simbol atau lambang.

Karena orang lain tidak dapat membaca pikiran dan perasaannya, maka perlu menterjemahkan bahasa mental tersebut ke dalam lambang yang dapat dimengerti orang lain. Proses penciptaan lambang disebut encoding.

Lambang-lambang atau simbol yang merupakan pernyataan pikiran dan perasaan, disusun menjadi bentuk visual yang sekaligus merupakan media untuk menyampaikan pesan. Ketika pesan tersebut diterima oleh komunikan, maka komunikan harus memecahkan lambang (decoding) yang diterimanya ke dalam perasaan, maksud, atau pikiran yang mempunyai suatu arti baginya. Dalam proses komunikasi, selain umpan balik (feedback) yang diperoleh dari orang lain (komunikan) sebagai reaksi dan penyampaian pesannya, diperoleh pula umpan balik dan pesan yang disampaikan sendiri (intra personal) baik secara kognitif maupun afektif. Secara idiil, gambaran mental antara komunikator dan komunikan harus sesuai, sehingga komunikasi dapat berjalan dengan baik meskipun pada kenyataannya yang sering dijumpai berbagai faktor yang melatarbelakangi ketidaksamaan pengalaman dari masing-masing dan penafsirannya terhadap arti atau makna dari lambang yang dihadapi, yang kemudian menimbulkan kesukaran atau hambatan dalam komunikasi.

Dalam teori komunikasi, lukisan sebagai bentuk visual yang berisikan tanda atau simbol-simbol yang merupakan penggambaran pesan yang hendak disampaikan. Tanda atau simbol yang berwujud kata atau gambar mempunyai dua aspek, yang ditangkap oleh indera kita disebut dengan signifier, bidang penanda atau bentuk, dan aspek lainnya yang disebut signified, bidang petanda atau konsep atau makna. Penanda terletak pada tingkatan ungkapan (Level of Expression), dan merupakan bagian fisik seperti bunyi, huruf, kata, gambar, warna, obyek, dan sebagainya. Petanda terletak pada tingkatan isi atau gagasan (Level of Content) dan apa yang diungkapkan melalui tingkatan ungkapannya. (Sumbo Tinarbuko, 2008 : 13). Hubungan antara kedua unsur tersebut melahirkan makna. Kedua hal tersebut merupakan satu kesatuan hubungan yang tidak dapat dipisahkan.

\section{HASIL DAN PEMBAHASAN}

Dalam kaji ulang, instrumen pengukuran respons estetik yang dikembangkan mengalami perbaikan baik dari segi isi, yaitu kesesuaian kata sifat bipolar dan stimulus lukisan dengan indikator respons estetik, serta konstruksi semantic differential. Hasil akhir instrumen pengukuran respons estetik siswa disajikan pada Gambar 1.

Analisis faktor dilakukan untuk memperoleh struktur faktor dari instrumen yang dikembangkan. Dari hasil korelasi antarbutir diperoleh nilai determinan 0,002 , sehingga dapat dilakukan proses komputasi analisis faktor. Untuk estimasi kecukupan sampel, KMO sampling adequacy menunjukkan nilai 0,80, yang berarti baik. Uji sferisitas (Barlett's test of sphericity) menunjukkan nilai chisquare $=396,564(d b=55), p<0,01$, yang berarti bahwa butir-butir tersebut bukan berasal dari populasi ubahan yang nonkolonier. Hasil estimasi komunalitas menunjukkan bahwa butir-butir instrumen pengukuran respons estetik ini memikili rata-rata komunalitas yang tinggi, yaitu 7,06, dan tidak ada butir instrumen yang memiliki komunalitas rendah.

\begin{tabular}{|r|ccccccc|l|}
\hline & \multicolumn{7}{|c|}{ LUKISAN NO. } & \\
\hline \multicolumn{1}{|c|}{ X } & 1 & 2 & 3 & 4 & 5 & 6 & 7 & \multicolumn{1}{|l|}{$X$} \\
\hline Terang & - & - & - & - & - & - & - & Gelap \\
Jelas & - & - & - & - & - & - & - & Kabur \\
Cemerlang & - & - & - & - & - & - & - & Kusam \\
Tidak indah & - & - & - & - & - & - & - & Indah \\
Sederhana & - & - & - & - & - & - & - & Rumit \\
Tenang & - & - & - & - & - & - & - & Kacau \\
Luwes & - & - & - & - & - & - & - & Kaku \\
Tidak mirip & - & - & - & - & - & - & - & Mirip \\
Hidup & - & - & - & - & - & - & - & Mati \\
Jelek & - & - & - & - & - & - & - & Bagus \\
Suka & - & - & - & - & - & - & - & Tidak suka \\
\hline
\end{tabular}

Gambar 1. Semantik Differential untuk Mengukur Respons Estetik Siswa SMP

Analisis faktor menghasilkan tiga komponen atau faktor. Faktor pertama memiliki proporsi varians $28,639 \%$, faktor kedua $22,076 \%$, dan faktor ketiga $19,933 \%$, sehingga secara kumulatif berjumlah $70.647 \%$. Komponen atau faktor pertama pada matriks di atas mencakup butir 'tidak indah-indah', 'jelek-bagus', 
'tidak suka-suka', 'tidak mirip-mirip', dengan muatan faktor. Kata sifat-kata sifat tersebut berhubungan dengan penilaian, maka faktor ini dapat diinterpretasikan sebagai faktor atau dimensi evaluatif. Faktor kedua mencakup butir 'gelap-terang', 'kusam-cemerlang', dan 'kabur-jelas'. Kata sifat-kata sifat tersebut secara umum berhubungan dengan kualitas (sifat-sifat) bentuk, maka faktor tersebut menunjukkan sebagai faktor potensi. Faktor ketiga mencakup butir-butir 'sederhana-rumit', 'hidup-mati', 'kacau-tenang', dan 'kaku-luwes'. Kata sifat-kata sifat tersebut berhubungan dengan gerak atau dinamika, maka faktor tersebu menunjukkan faktor atau dimensi aktivitas. Jadi, hasil analisis faktor tersebut sesuai dengan dimensi-dimensi makna menurut Osgood, Suci, dan Tannenbaum. Matriks faktor yang dihasilkan dapat dilihat pada Tabel 1.

Pengamatan karya seni rupa pada dasarnya adalah pengamatan terhadap bentuk. Apresiasi karya seni rupa melibatkan respons terhadap kualitas bentuk. Bentuk dalam bahasa Inggris adalah 'form' dan, dalam kajian seni rupa, kata 'formal' digunakan untuk mengidentifikasi konsep yang berhubungan dengan bentuk, misalnya 'formal elements' (unsur-unsur bentuk) atau 'formal analysis' (analisis bentuk). Oleh karena itu, untuk faktor potensi dapat dinamakan sebagai 'faktor formal'.

Tabel 1

Matriks Faktor Instrumen

\begin{tabular}{|l|c|c|c|}
\hline \multirow{2}{*}{\multicolumn{1}{c|}{ Butir }} & \multicolumn{3}{|c|}{ Faktor } \\
\cline { 2 - 4 } & 1 & 2 & 3 \\
\hline tidak indah-indah & 0,897 & 0,115 & $-0,054$ \\
jelek-bagus & 0,871 & 0,138 & 0,231 \\
tidak suka-suka & 0,810 & 0,313 & 0,331 \\
tidak mirip-mirip & 0,616 & 0,053 & 0,469 \\
gelap-terang & $-0,021$ & 0,891 & $-0,043$ \\
kusam-cemerlang & 0,206 & 0,849 & 0,091 \\
kabur-jelas & 0,233 & 0,784 & 0,201 \\
sederhana-rumit & $-0,092$ & $-0,020$ & 0,811 \\
hidup-mati & 0,441 & 0,041 & 0,674 \\
kacau-tenang & 0,338 & 0,209 & 0,656 \\
kaku-luwes & 0,369 & 0,347 & 0,462 \\
\hline
\end{tabular}

Dalam seni rupa, gerak atau dinamika merupakan unsur yang membangkitkan atau merangsang perasaan (emosi). Untuk faktor ini, Newton (1989) menggunakan istilah 'arousal', yang sama artinya dengan kata 'stimulative'. Oleh karena itu, faktor ketiga tersebut di sini dinamakan 'dimensi stimulatif'.
Sedangkan yang ditangkap atau ditanggapi pada saat mengamati bentuk visual, adalah potensi kualitatif pengalaman estetis atau yang sering disebut dengan kesatuan hubungan nilai-nilai atau struktur estetis (E.B. Feldman, 1967 : 276).

Apabila seseorang berhasil menangkap struktur estetis dari sebuah karya seni (lukisan) selanjutnya ia akan dapat pula menangkap makna atau isi karya tersebut. Lukisan berhubungan dengan penampilan rupa yang dapat dicerap oleh orang banyak, dengan pikiran maupun perasaannya. Rupa yang mengandung pengertian atau makna, karakter serta suasana, yang mampu dipahami (diraba dan dirasakan) oleh khalayak umum atau terbatas.

Seni lukis pada akhir-akhir ini mengalami perkembangan yang sangat pesat, baik ide-ide kreatif, tema, corak atau gaya, yang digarap lebih kompleks, berbeda dengan masa lalu yang masih menggarap tema-tema keindahan alam, potret dan sejenisnya, dan secara teknis lebih variatif, menggunakan berbagai bahan dan alat yang lebih kaya jenisnya. Begitu pula dalam penyelenggaraan pameran seni lukis, tidak hanya menampilkan lukisan-lukisan yang berbobot saja melainkan mengaplikasikan juga berbagai media komunikasi visual dengan mengolah dan memasukkan elemen-elemen gambar, huruf, cahaya serta musik. Semua dirancang sedemikian rupa sehingga tampil maksimal. Ini semua dilakukan guna menyampaikan pesan dalam bentuk lukisan agar terjadi proses komunikasi dan tujuan komunikasi. Dalam hal ini, lukisan digunakan sebagai media komunikasi untuk menyampaikan pesan.

\section{BENTUK SEBAGAI MEDIA DALAM SENI LUKIS}

Telah diuraikan pada bab sebelumnya tentang bentuk dalam seni lukis. Bentuk di sini yang dihasilkan dan dapat diamati sebagai bentuk visual. Melalui bentuk visual tersebut, pelukis menciptakan lambang, simbol, atau ikon yang mewakili pikiran, perasaan, dan emosinya kepada manusia di luar dirinya (apresiator/komunikan). Bentuk di sini merupakan media komunikasi.

Adapun media yang dimaksud di sini adalah media sekunder atau media yang bersifat fisik atau terwujud. Dalam proses komunikasi terdapat dua jenis media untuk menyampaikan pikiran sebagai isi pesan. Media pertama adalah lambang, baik verbal maupun nirverbal. Sedangkan media sekunder adalah media yang berwujud yang sebagaimana disebutkan diatas (Onong U.E, 2003 : 397).

Para ahli ilmu komunikasi mengembangkan model-model komunikasi yang berfungsi untuk memberi gambaran lebih jelas tentang proses komunikasi. Menurut Adler dan Rodman (1982) dikutip oleh Umar Suwito (1989:12) mencoba menggambarkan langkah-langkah dalam proses komunikasi antar pribadi (komunikasi interpersonal), sebagai berikut : 
menangkap pesan yang disampaikan. Dalam hal ini, berupa bentuk pada lukisan, maka perlu kiranya untuk memahami prinsip-prinsip dasar komunikasi dan faktorfaktor penunjang dan penghambat yang harus menjadi perhatian. Hal inilah yang akan penulis uraikan pada bab-bab selanjutnya.

\section{BENTUK DALAM SENI LUKIS}

Sebuah benda seni harus memiliki wujud, agar dapat diterima secara inderawi (dilihat, didengar atau dilihat dan didengar) oleh orang lain. Benda seni itu suatu wujud fisik, tetapi wujud fisik tersebut tidak secar otomatis menjadi karya seni. Berseni atau tidaknya suatu wujud fisik tersebut ditentukan oleh nilai yang ada di dalamnya. Apakah wujud itu berhasil merangsang timbulnya nilai-nila pada orang lain?. Nilai itu bersifat subyektif. Benda seni atau lukisan hanya obyek, yang kepadanya dapat diberikan nilai-nilai oleh subyek penerima seni. Setiap subyek penerima seni yang satu bisa jadi akan memberikan nilai yang berbeda dengan lainnya. Ini disebabkan adanya perbedaan pengalaman estetis, intelektual, wawasan yang dimiliki oleh masing-masing penerima seni tersebut, bahkan dapat berbeda pula dengan yang dimaksud oleh senimannya sendiri. Baginya isi karya merupakan pengalaman dan tujuan yang hendak dicapai. Sejauh semuanya itu tertuang dalam bentuk, sebagai simbol langsung. Hal ini merupakan wujud atau benda dapat disebut bernilai seni, apabila subyek pengamatnya, karena benda tersebut mengandung kemampuan untuk merangsang diberikannya berbagai nila oleh subyeknya. Begitu pula pada lukisan, yang menurut Edmund Burke Feldman menamakan bentuk yang dihasilkan dan dapat diamati sebagai bentuk visual Artinya, bentuk itu ditinjau dari unsur-unsur penyusunan yang berpedoman pada azas-azas desain (Principle of Design). Azas-azas yang dimaksud adalah unity balance, rhythm, proportion. Unity atau kesatuan diciptakan melalui sub-azas device, domination, dan sub-ordination (yang utama dan kurang utama) Dominace diupayakan lewat ukuran, warna, dan tempat atau lokasi serta convergence dan perbedaan atau pengecualian (Defference of Exception) (Humar Sahman, 1993: 43). Dalam menghadapi hasil karya seni (lukisan) menuru Feldman dibedakan antara visual form dengan aesthetic structure. Yang pertama adalah benda seninya, sedangkan yang kedua yaitu hasil pengamatan kita. Visual form adalah obyektif, dan aesthetic structure adalah subyektif. Orang sama-sama memiliki penglihatan sempurna sekalipun, tidak akan bisa memperoleh pengalaman yang sama dalam menanggapi suatu hasil seni yang sama. Bukan itu saja bahkan orang yang samapun akan memperoleh pengalaman yang berbeda dalam menanggapi barang yang sama tersebut dalam waktu yang berbeda, orang mempunyai latar belakang pengalaman yang berbeda, minat atau mood seseorang pada suatu saat yang berbeda minat akan besar pengaruhnya terhadap pembentukan aesthetic structure ((Humar Sahman, 1993: 153).
Dengan demikian, respons estetik diklasifikasikan menjadi 'respons evaluatif', 'respons formal', dan 'respons stimulatif'.

Hasil analisis reliabilitas Cronbah's alpha yang diperoleh adalah 0,85. Hal ini berarti bahwa instrumen memiliki konsistensi internal yang tinggi (di atas 0,6 ). Analisis korelasi intraklas $\left(r_{i j}\right)$ menghasilkan nilai 0,73 . Jadi, instrumen respons yang dikembangkan menunjukkan konsistensi internal dan stabilitas yang tinggi.

Untuk mengetahui sensitivitas instrumen tersebut, analisis hasil uji coba ini diteruskan dengan melihat pengaruh faktor gaya lukisan dan faktor tema lukisan terhadap respons estetik siswa. Di sini digunakan analisis variansi dengan pengukuran ulang, karena data skor untuk faktor gaya maupun tema diambil dari subjek yang sama. Dalam analisis ini respons estetik merupakan ubahan terikat, sedangkan gaya dan tema merupakan faktor dalam subjek (within subject factor). Gaya terdiri atas tiga kategori, yaitu naturalistik (tanpa abstraksi), abstraksi sedang, dan abstraksi tinggi, sedangkan tema terdiri atas empat kategori, yaitu alam benda, pemandangan alam, potret pria, dan potret wanita. Jadi, rancangan yang digunakan adalah ANAVA 3 X 4 .

Berdasarkan uji univariat Greenhouse-Geisser, dapat diketahui sebagai berikut: (1) Ada pengaruh gaya yang signifikan pada respons evaluatif $F(1,835$, $126,623)=230,967, p<0,01$; (2) Ada pengaruh tema yang signifikan pada respons evaluatif $F(2,691,185,653)=57,058, p<0,01$; ; (3) Ada interaksi pengaruh gaya dan tema yang signifikan pada respons evaluatif $F(5,216,359,871)$ $=32,910, p<0,01$. Besar pengaruh (effect size) faktor gaya pada respons evaluatif $\left(\eta^{2}=0,770\right)$ menunjukkan nilai yang tinggi, sedangkan pengaruh faktor tema $\left(\eta^{2}=\right.$ $0,458)$ dan pengaruh interaksi faktor gaya dan tema $\left(\eta^{2}=0,323\right)$ menunjukkan nilai yang relatif rendah. Ringkasan uji univariat ini dapat dilihat pada Tabel 2 , sedangkan pengaruh gaya dan tema serta interaksinya terhadap respons formal dapat dilihat pada Gambar 2.

Tabel 2 Ringkasan Hasil Uji Pengaruh dalam Subjek Faktor Gaya dan Tema Lukisan pada Respons Evaluatif

\begin{tabular}{|c|c|c|c|c|c|c|}
\hline Sumber & $\begin{array}{l}\text { Jumlah } \\
\text { Kuadrat } \\
\text { Tipe III }\end{array}$ & $d b$ & $\begin{array}{l}\text { Rerata } \\
\text { Kuadrat }\end{array}$ & $F$ & Sig. & $\begin{array}{c}\text { Eta } \\
\text { Kuadrat } \\
\left(\eta^{2}\right)\end{array}$ \\
\hline GAYA & 4208.930 & 2 & 2104.465 & 230.967 & 0.000 & 0.770 \\
\hline Error(GAYA) & 1257.394 & 138 & 9.112 & & & \\
\hline TEMA & 1399.010 & 3 & 466.337 & 58.285 & 0.000 & 0.458 \\
\hline Error(TEMA) & 1656.194 & 207 & 8.001 & & & \\
\hline $\begin{array}{c}\text { GAYA * } \\
\text { TEMA }\end{array}$ & 991,261 & 6 & 165,210 & 32,861 & 0,000 & 0,323 \\
\hline $\begin{array}{c}\text { Error(GAYA* } \\
\text { TEMA) }\end{array}$ & 2081,406 & 414 & 5,028 & & & \\
\hline
\end{tabular}




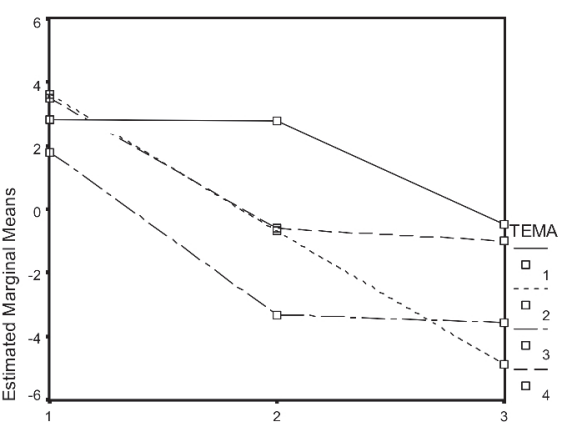

GAYA

Gambar 2. Pengaruh Faktor Gaya, Tema, dan Interaksinya pada Respons Evaluatif

Berdasarkan uji univariat Sphericity Assumed, dapat diketahui sebagai berikut: (1) Ada pengaruh gaya yang signifikan pada respons formal, dengan nilai $F(2,138)=183,521, p<0,01 ;(2)$ Ada pengaruh tema yang signifikan pada respons formal, dengan nilai $F(3,207)=15,681, p<0,01$; (3) Ada interaks pengaruh gaya dan tema yang signifikan pada respons formal, dengan nilai $F(6$, $414)=66,870, p<0,01$. Besar pengaruh (effect size) faktor gaya pada respons formal $\left(\eta^{2}=0,727\right)$ menunjukkan nilai yang tinggi, sedangkan pengaruh faktor tema $\left(\eta^{2}=0,185\right)$ dan pengaruh interaksi faktor gaya dan tema $\left(\eta^{2}=0,492\right)$ menunjukkan nilai yang relatif rendah. Ringkasan uji univariat ini dapat dilihat pada Tabel 3, sedangkan pengaruh gaya dan tema serta interaksinya terhadap respons formal dapat dilihat pada Gambar 3 .

Tabel 3 Ringkasan Hasil Uji Pengaruh dalam Subjek Faktor Gaya dan Tema Lukisan pada Respons Formal

\begin{tabular}{|c|c|c|c|c|c|c|}
\hline Sumber & $\begin{array}{c}\text { Jumlah } \\
\text { Kuadrat } \\
\text { Tipe III }\end{array}$ & $d b$ & $\begin{array}{c}\text { Rerata } \\
\text { Kuadrat }\end{array}$ & $F$ & Sig. & $\begin{array}{c}\text { Eta } \\
\text { Kuadrat } \\
\left(\mathrm{m}^{2}\right)\end{array}$ \\
\hline GAYA & 1313.393 & 2 & 656.697 & 183.521 & 0.000 & 0.727 \\
Error(GAYA) & 493.809 & 138.000 & 3.578 & & & \\
TEMA & 231.543 & 3 & 77.181 & 15.681 & 0.000 & 0.185 \\
$\begin{array}{c}\text { Error(TEMA) } \\
\text { GAYA * } \\
\text { TEMA }\end{array}$ & 1018.834 & 207 & 4.922 & & & \\
$\begin{array}{c}\text { Error(GAYA* } \\
\text { TEMA) }\end{array}$ & 1256,569 & 414 & 3,035 & & & \\
\hline
\end{tabular}

itulah yang disusun dan disatupadukan sehingga menjadi sebuah kebulatan yang utuh. Pengorganisasian itu harus mengandung makna dan menarik, sehingga terjelma apa yang dikenal sebagai bentuk (form) dari karya seni.

Sejalan dengan pendapat tersebut maka Humar Sahman (1993: 41) dalam bukunya yang berjudul "Mengenali Dunia Seni Rupa" mengutip pendapat Edgar de Bruyne yang menyatakan bahwa bentuk adalah wujud lahiriah.

Dengan demikian dalam karya seni, bentuk adalah wujud lahiriah yang merupakan organisasi medium berikut unsur-unsur seni, sehingga menjadi kebulatan yang utuh dan pengorganisasian tersebut harus bermakna dan menarik. Bentuk inilah yang merupakan bungkus dari isi atau konten.

Lukisan merupakan suatu wujud simbol atau bahasa visual yang di dalamnya terkandung struktur rupa seperti garis, warna, dan komposisi. Ini dikelompokkan dalam kategori bahasa komunikasi non verbal dan dibedakan dengan bahasa verbal yang berwujud tulisan atau ucapan. Dalam lukisan bentukbentuk yang diekspresikan sebagai simbol visual, yang memiliki karakteristik, khas, dan menimbulkan kesan tertentu bagi penikmatnya, meskipun tidak dapat dipungkiri bahwa dalam penikmatan sebuah karya seni (lukisan), pesan yang disampaikan dalam bentuk simbol tersebut seringkali pemaknaan dari symbolsimbol tersebut berbeda antara satu penikmat dengan penikmat lainnya, mengingat interpetasi yang bersifat subyektif. Hal ini akan berbeda jika dibandingkan dengan penikmatan pada karya-karya desain komunikasi visual, yang melalui bentuk simbol visual yang fungsi utamanya adalah fungsi komunikasi, tetapi bentukbentuk komunikasi visual juga mempunyai fungsi signifikansi yaitu fungsi dalam menyampaikan sebuah konsep, isi atau makna. Ini akan berbeda dengan bidang seni rupa, seni lukis khususnya yang tidak mempunyai fungsi khusus komunikasi seperti itu, akan tetapi ia memiliki fungsi signifikansi. Jadi meskipun semua muatan komunikasi dari bentuk-bentuk komunikasi visual ditiadakan ia sebenarnya masih mempunyai muatan signifikansi, yaitu muatan makna (Sumbo Tinarbuko, 2008: xi).

Perbedaan- perbedaan dalam setiap cabang seni merupakan hal yang wajar dan sangat dimungkinkan. Misalnya: seni murni, seni lukis dan seni patung, yang merupakan hasil ekspresi pribadi, tuntutan berasal dari dirinya sendiri, sedangkan desain komunikasi visual, dekorasi atau seni kriya atau seni terapan lainnya akan dibebani aspek fungsionalnya atau kegunaan praktis. Oleh karenanya Faktor diluar dirinya menjadi hal yang penting, misalnya : selera masyarakat, trend yang sedang berkembang, sehingga karya yang dihasilkan dapat diminati.

Namun keduanya terdapat kesamaan dalam hal komunikasi, yaitu dalam proses penyampaian ide, pemikiran, pendapat atau berita ke suatu tempat tujuan serta menimbulkan reaksi umpan balik dari masyarakat (komunikan). Agar komunikasi berjalan secara efektif, artinya penikmat seni atau komunikan dapat 
dan memberi informasi, mempengaruhi orang lain, serta mempertimbangkan solusi alternatif atas masalah dan mengambil keputusan dalam kehidupan sosia serta hiburan. Komunikasi dalam kehidupan sehari- hari dapat digunakan sebagai interaksi dengan proses sebab akibat, atau aksi reaksi yang bergantian arahnya, sehingga terjadi umpan balik antara sumber pesan ke penerima pesan.

Pada tahap komunikasi masih dianggap sederhana, dimana melalui komunikasi orang berusaha mendefinisikan sesuatu yang terus menerus berkesinambungan. Dalam perkembangannya, komunikasi tidak hanya dalam bentuk kata-kata, tetapi berkembang ke bentuk-bentuk simbolik yang memberikan makna-makna tertentu. Komunikasi dalam bentuk sibol ini merupakan sesuatu yang lainnya berdasarkan kesepakatan. Pada dasarnya simbol atau lambang tidak mempunyai makna, dan manusianya sendirilah yang memberikan makna pada lambang tersebut. Dengan demikian, komunikasi dengan bentuk simbol atau lambang dapat diasosiasikan dengan citra tertentu sesuai dengan maknanya.

Dalam penerapannya, komunikasi dapat mengapresiasikan bentuk simbolisasi dan makna. Komunikasi dalam bentuk simbol sangat bervariasi, dapa berupa bentuk, gaya, gerak, komposisi warna, garis, bidang, tekstur, gelap terang, bahasa tubuh atau bahasa isyarat, baik bentuk fisik maupun non fisik, sesuai dengan makna yang diberikan pada simbol tersebut.

Bagi pelukis sebagai individu, seperti yang lainnya, juga membutuhkan berkomunikasi dengan manusia di luar dirinya. Melalui lukisan yang diciptakan inilah pelukis berkomunikasi dengan masyarakat sebagai penikmat seni atau komunikan.

Seni lukis merupakan salah satu cabang seni rupa. Seni lukis adalah pengungkapan atau pengucapan pengalaman artistik yang ditampilkan dalam bidang dua dimensional dengan menggunakan garis dan warna (Soedarso $\mathrm{Sp}$, 1990: 11). Sedangkan I. A. Richards penganut teori komunikasi, ia melihat sen sebagai kegiatan komunikasi yang disejajarkannya dengan teori kebahasaan dalam membuat telaah tentang seni dan penulis buku "The Cinema as Art" melihat seni sebagai proses menyeleksi dan menyusun buah pengalaman, intuisi atau inspirasi dalam wujud karya seni yang benar dan indah, yang sedikit banyak mengacu pada kenyataan, dengan maksud agar karya tersebut dapat mengkomunikasikan pengalaman dan lain sebagainya itu kepada para pengamatnya (Humar Sahman, 1993: 19). Melalui karya seninya dalam bentukbentuk signifikan yang merupakan bahasa visual, menyampaikan ide-ide atau gagasan, emosi, intuisi atau yang diyakininya. Melalui bentuk-bentuk berupa lambang atau tanda-tanda, yang dalam hal ini seniman menyampaikan arti dan nilai satu sama lainnya. Bentuk dalam karya seni khususnya lukisan, menurut The Liang Gie (1983: 70) dalam bukunya yang berjudul Garisbesar Estetik (Filsafat Keindahan) menyatakan bahwa dalam setiap karya seni, medium berikut unsurnya

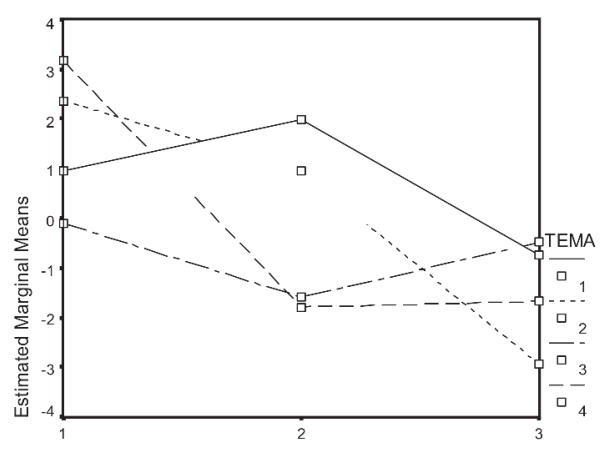

GAYA

Gambar 3. Pengaruh Faktor Gaya, Tema, dan Interaksinya pada Respons Formal

Berdasarkan uji univariat Sphericity Assumed, dapat diketahui sebagai berikut: (1) Ada pengaruh gaya yang signifikan pada respons stimulatif, dengan nilai $F(2,138)=217,817, p<0,01$; (2) Ada pengaruh tema yang signifikan pada respons stimulatif, dengan nilai $F(3,207)=64,541, p<0,01$; (3) Ada interaksi pengaruh gaya dan tema yang signifikan pada respons stimulatif, dengan nilai $F$ $(6,414)=26,585, p<0,01$. Besar pengaruh (effect size) faktor gaya pada respons stimulatif $\left(\eta^{2}=0,759\right)$ menunjukkan nilai yang tinggi, sedangkan pengaruh faktor tema $\left(\eta^{2}=0,483\right)$ dan pengaruh interaksi faktor gaya dan tema $\left(\eta^{2}=0,278\right)$ menunjukkan nilai yang relatif rendah. Ringkasan uji univariat ini dapat dilihat pada Tabel 4, sedangkan pengaruh gaya dan tema serta interaksinya terhadap respons formal dapat dilihat pada Gambar 4

Tabel 4 Ringkasan Hasil Uji Pengaruh dalam Subjek Faktor Gaya dan Tema Lukisan pada Respons Stimulatif

\begin{tabular}{|c|c|c|c|c|c|c|}
\hline Sumber & $\begin{array}{c}\text { Jumlah } \\
\text { Kuadrat }\end{array}$ & $d b$ & $\begin{array}{c}\text { Rerata } \\
\text { Kuadrat }\end{array}$ & $F$ & Sig. & $\begin{array}{c}\text { Eta } \\
\text { Kuadrat }\end{array}$ \\
\hline & Tipe III & & & & & $\left.\eta^{2}\right)$ \\
\hline GAYA & 1540.231 & 2 & 770.115 & 217.817 & 0.000 & 0.759 \\
Error(GAYA) & 487.914 & 138.000 & 3.536 & & & \\
TEMA & 668.278 & 3 & 222.759 & 64.541 & 0.000 & 0.483 \\
Error(TEMA) & 714.450 & 207 & 3.451 & & & \\
GAYA * & 397,251 & 6 & 66,209 & 26,585 & 0,000 & 0,278 \\
TEMA & & 414 & 2,490 & & & \\
$\begin{array}{c}\text { Error(GAYA* } \\
\text { TEMA) }\end{array}$ & 1031,026 & 4 & & & & \\
\hline
\end{tabular}




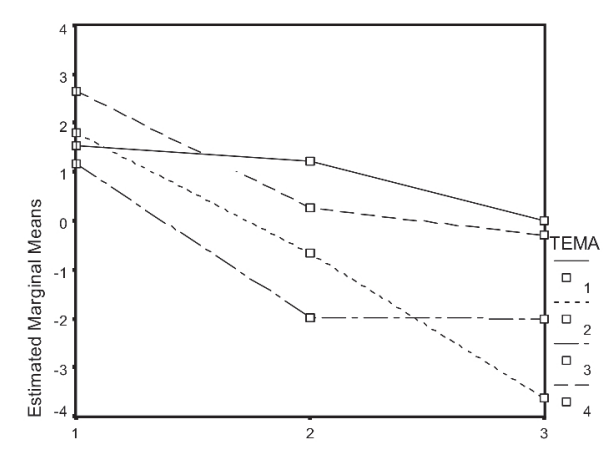

GAYA

Gambar 4. Pengaruh Faktor Gaya, Tema, dan Interaksinya pada Respons Stimulatif

Berdasarkan hasil analisis data yang telah dilakukan, instrumen respons estetik ini yang dikembangkan ini menunjukkan kualitas yang baik. Namun demikian, instrumen ini masih memiliki keterbatasan sebagai berikut: (1) Semantic differential terbatas pada tiga faktor atau dimensi makna menurut Osgood dkk (faktor evaluatif, potensi, dan aktivitas), belum mencakup faktorfaktor yang lain yang dapat meningkatkan validitasnya dalam mengukur respons estetik siswa; (2) Kata 'tidak indah', 'tidak mirip', dan 'tidak suka' bukan merupakan kata sifat yang murni, karena menggunakan kata 'tidak'; (3) Pengertian gaya terbatas pada aspek penggambaran objek (naturalistik, semideformatif, dan deformatif), belum mencakup aspek konsep ekspresi (sebagai aliran, seperti realisme, impresionisme, simbolisme, ekspresionisme, dan kubisme); (4) Pengertian tema terbatas jenis objek yang digambarkan (alam benda, pemandangan alam, potret pria, dan potret wanita), belum mencakup aspek naratif (sebagai isi, seperti misalnya tema kemanusian, kesejarahan, sosial, dan pengalaman psikologis); (5) Stimulus lukisan belum dibedakan menurut asa penciptanya (pelukis Indonesia dan pelukis Mancanegara).

\section{SIMPULAN}

Berdasarkan hasil penelitian tentang pengembangan instrumen pengukuran respons estetik untuk siswa SMP dengan menggunakan semantic differential, dapat disimpulkan sebagai berikut:

1. Untuk menghasilkan instrumen pengukuran respons estetik untuk siswa SMP yang valid dan reliabel, dilakukan prosedur sebagai berikut: (a) penyusunan kisi-kisi untuk menetapkan butir-butir semantic differential dan pemilihan lukisan yang digunakan sebagai objek tanggapan, (b) penyusunan instrumen

\section{BENTUK SEBAGAI MEDIA KOMUNIKASI DALAM SENI LUKIS}

\section{Djoko Maruto} FBS Universitas Negeri Yogyakarta

\section{Abstract}

This article discusses forms in painting art. Forms are visual structure consisting of lines, shapes and colors arranged in two dimentional shapes based on artistic principles. The visual structure can be simbols or icons as visualization of ideas, feelings and emotions. Through this visual language containing messages artists communicate with themselves and other people. In this piece messages artists communicate with themselves and other people. In this piece of writting, forms are nedia to deliver messages, and they are highlighted from communication science. This study was conducted to know whether the form are icons, index or symbols used to convey messages to the appreciants, as well as the communication processes and conditions that must be created so that the communication through paintings flows as expected, meaning that there is feedback from the appreciant or communicant to the painter or the communicator.

Keywords: form, media of communication, painting art

\section{PENDAHULUAN}

Manusia adalah mahkluk individu dan sosial. Dalam hubungannya dengan mahkluk sosial, maka manusia bagaimanapun juga tidak dapat terlepas dari individu yang lain. Secara kodrati manusia akan selalu hidup bersama dan saling membutuhkan satu dengan lainnya. Hidup bersama antar manusia berlangsung dalam berbagai bentuk komunikasi dan situasi yang mempengaruhi.

Komunikasi dapat terjadi pada siapa saja, dan melakukan komunikasi adalah merupakan bagian kebutuhan penting dari seluruh aktivitas. Semuanya agar terjadi pengertian, jalinan hubungan dan pengertian bersama.

Kata komunikasi (Bahasa Inggris : Communication) berasal dari kata kerja Latin "Communicare", yang berarti berbicara bersamaan, berunding, berdiskusi, dan berkonsultasi satu sama lain. Dalam kehidupan sehari-hari, penggunaan kata komunikasi dalam arti : berhubungan dengan orang lain, menyampaikan pernyataan, pikiran, atau perasaan kepada orang lain dengan atau tanpa menggunakan media (Umar Suwito, 1989 : 1). Rumusan pengertian komunikasi lain yang sering kita dengar ialah, bahwa komunikasi merupakan proses penyampaian informasi berupa lambing yang mengandung arti atau makna, dan informasi yang disampaikan itu akan menjadi milik bersama.

Pada dasarnya komunikasi merupakan suatu pemahaman bentuk dasar adaptasi terhadap lingkungan. Komunikasi sangat dibutuhkan untuk memperoleh 